\title{
Viral infections detected by serology and PCR of perilymphatic fluid in children with idiopathic sensorineural hearing loss
}

\author{
S. Noorbakhsh, ${ }^{1}$ M. Farhadi, ${ }^{2}$ A. Daneshi, ${ }^{2}$ S. Mohamadi ${ }^{2}$ and A. Tabatabaei ${ }^{1}$
}

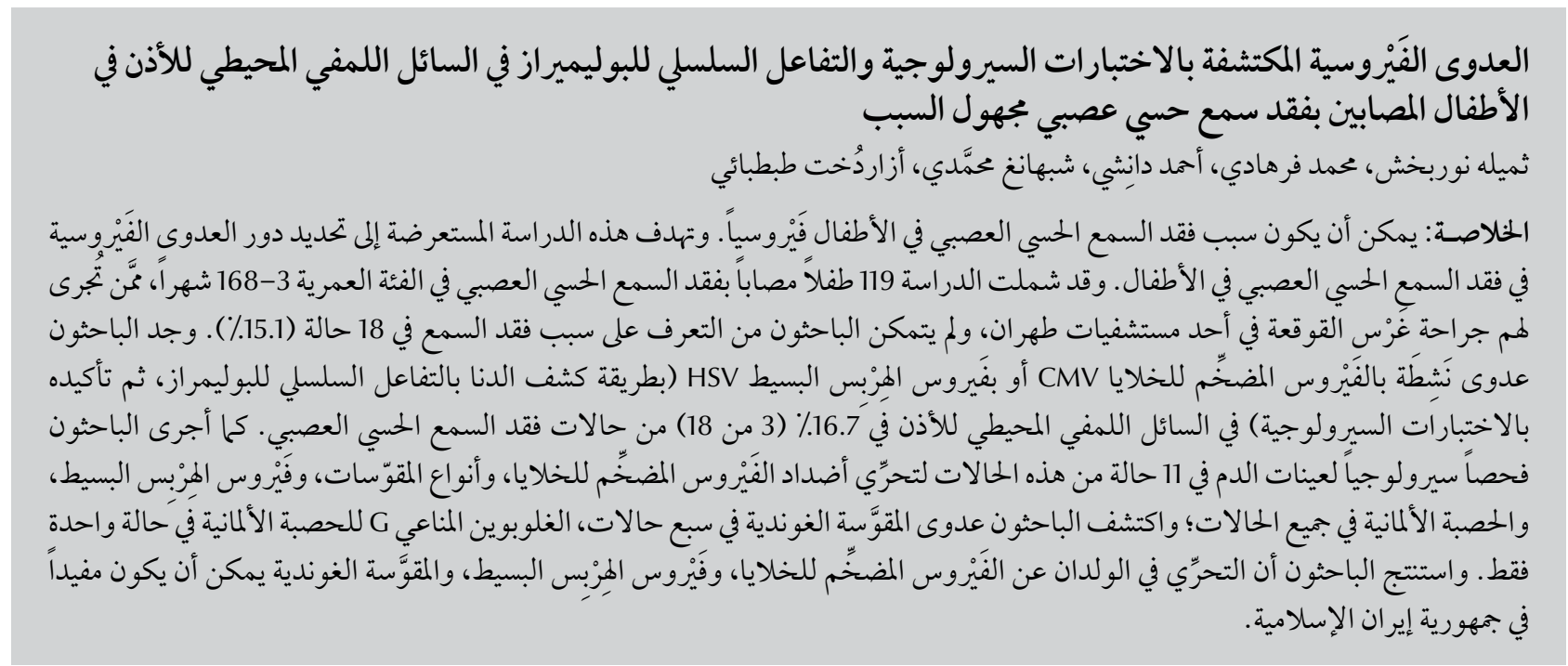

ABSTRACT The etiology of sensorineural hearing loss (SNHL) in children may be viral. This cross-sectional study aimed to determine the role of viral infectious agents in children with idiopathic SNHL. Of 119 children with SNHL aged 3-168 months undergoing cochlear implant surgery at a hospital in Tehran, no cause could be established in 18 cases (15.1\%). Cytomegalovirus (CMV) and herpes simplex virus (HSV) active infections (detected by DNA-PCR, confirmed by serology) were found in the perilymphatic fluid of $16.7 \%$ (3/18) cases of idiopathic SNHL. Serology was performed on blood samples from 11 of these cases: specific antibodies against CMV, Toxoplasma spp., HSV and rubella were determined in all cases; acute T. gondii infection was detected in 7 cases and rubella IgG was found in only 1 case. Neonatal screening for CMV, HSV and T. gondii may be helpful in the Islamic Republic of Iran.

Infections virales dépistées par sérologie et amplification génique du liquide périlymphatique chez des enfants atteints d'une surdité neurosensorielle idiopathique

RÉSUMÉ La cause de la surdité neurosensorielle chez les enfants peut être virale. La présente étude transversale visait à déterminer le rôle des agents infectieux viraux chez les enfants atteints d'une surdité neurosensorielle idiopathique. Sur 119 enfants âgés de 3 à 168 mois atteints de cette pathologie et entreprenant une implantation cochléaire dans un hôpital de Téhéran, aucune cause n'a pu être établie dans 18 cas (15,1 \%). Des infections actives à cytomégalovirus et par le virus de I'herpès (dépistées par amplification génique de l'ADN et confirmées par sérologie) ont été observées dans le liquide périlymphatique de 16,7 \% des cas (3/18). Une analyse sérologique a été réalisée sur les échantillons de sang de 11 de ces cas : des anticorps spécifiques contre le cytomégalovirus, Toxoplasma spp., le virus de l'herpès et la rubéole ont été déterminés dans tous les cas; une infection aiguë à Toxoplasma gondii a été détectée dans sept cas et des anticorps IgG antirubéoleux ont été retrouvés dans un cas unique. Un dépistage néonatal du cytomégalovirus, du virus de l'herpès et de Toxoplasma gondii pourrait être utile en République islamique d'Iran.

${ }^{7}$ Paediatric Infectious Diseases Research Centre; ${ }^{2}$ Ear, Nose and Throat Diseases Research Centre, Tehran University of Medical Sciences, Tehran, Islamic Republic of Iran (Correspondence to S. Noorbakhsh:Samileh_noorbakhsh@yahoo.com; CPIDIR@gmail.com).

Received: 12/06/09; accepted: 15/04/10 


\section{Introduction}

Sensorineural hearing loss (SNHL) is a type of hearing loss in which the root cause lies in the vestibulocochlear nerve (cranial nerve VIII), the inner ear or the central processing centres of the brain [1]. While hearing loss can be inherited, acquired hearing loss can occur at any time in a person's life. Some conditions that can result in acquired hearing loss, especially in children are ear infections (otitis media), ototoxic drugs, meningitis, measles, encephalitis, chickenpox, influenza, mumps, head injury and excessive noise exposure [2]. Idiopathic (unexplained) hearing loss may be the result of an infectious disease or an injury [1].

The etiology of SNHLis unknown in as many as $40 \%$ of children, even though some evidence suggests that it can be viral in origin [3-8]. Many authors have reported congenital cytomegalovirus (CMV) as the most common cause of nonhereditary SNHL in children, second only to genetic mutations, and therefore potentially preventable [3-8]. Until the last decade, CMV had only been detected in the inner ear fluid of patients who died due to complications of symptomatic congenital CMV infection. Davis et al., however, recovered CMV from the living human inner ear fluid without cochlear damage [9]. Sugiura et al. found CMV DNA in clinical samples (including perilymph) collected from 5 patients with deafness using realtime polymerase chain reaction (PCR) methods [10].

Screening for intrauterine infections during pregnancy or in neonates is not available in the Islamic Republic of Iran [11]. Previous serological studies in Tehran showed that CMV and Toxoplasma gondii infection may play a major role in children with congenital or acquired forms of SNHL [12-14]. The aim of this study was to determine the prevalence of viral infectious agents, principally CMV and herpes simplex virus (HSV), in children with idiopathic SNHL, using DNA analysis of perilymphatic fluid from cochlear implant surgery and serology findings.

\section{Methods}

\section{Setting and sample}

This cross-sectional study was carried out in the cochlear implant centre of Rasul Akram hospital in Tehran from 2006 to 2008 . This study was approved by the ethical committee of Rasul hospital, which is affiliated to the Iran University of Medical Sciences. We studied 119 SNHL children having cochlear implant surgery, ranging in age from 3 to 168 months.

\section{Data collection}

A questionnaire was completed by an authorized physician for each case. Audiologicalscreening (auditorybrainstem response, evoked otoacoustic emissions and pure tone audiometry) appropriate for age was used in all cases. Diagnostic parameters for profound SNHL and idiopathic SNHL were based on American Academy of Otolaryngology criteria [1].

During cochlear implant surgery, we obtained perilymphatic fluid samples from the 18 cases of idiopathic SNHL and analysed them for CMV and HSV DNAs. The surgeon collected the perilymphatic fluid into sterile microtubes. Samples were transferred immediately to our research laboratory. The samples were kept frozen at $-80^{\circ} \mathrm{C}$ and DNA extraction was done using a PCR template purification kit (NucleoSorb, Quiagen). In the first step HSV-1 DNA was searched by conventional qualitative PCR (Roche). For definite diagnosis the quantification kit for detection the CMV genomes (PrimerDesign ${ }^{\mathrm{TM}}$ using the TaqMan ${ }^{\circledR}$ principle) was done in all samples.

Adequate blood samples were available for 11 of 18 idiopathic SNHL cases. Specific antibodies against CMV,
Toxoplasma spp., HSV-1 and rubella were determined in the serum. Blood samples $(2 \mathrm{~mL})$ were obtained on the day before surgery and centrifuged. Samples were transferred and kept frozen at $-20^{\circ} \mathrm{C}$ in our research laboratory. Enzyme-linked immunosorbent assay (ELISA) (BioChem ImmunoSystems) for specific IgM and IgG antibodies was carried out. Both kits were used and the results were calculated qualitatively. The results were interpreted by cut-off controls according to the manufacturer's instructions.

\section{Statistical analysis}

Student t-test was used to determine significant differences in means and standard deviation (SD) for all continuous variables. Chi-squared values were calculated for all categorical variables. $P<0.05$ was taken as significant. All analyses were conducted using SPSS, version 11.5.

\section{Results}

\section{Profile of SNHL cases}

The mean age of the 119 SNHL cases at cochlear implant surgery was 32 (SD $28)$ months; $47.0 \%(56 / 108)$ were male and 53\% $(67 / 108)$ were female (data missing for 11 cases). One or multiple causes for SNHL were diagnosed in $84.9 \%(101 / 119)$ of these cases: hyperbilirubinaemia in $22.7 \%$ (27); familial type in $20.2 \%$ (24); postnatally known infectious diseases (mumps, chickenpox, sepsis, otitis media, etc.) in $16.0 \%$ (19); convulsions in $11.8 \%$ (14); radiation in 8.4\% (10); mental retardation in $8.4 \%(10)$; neonatal hypoxaemia in $1.7 \%(2)$; trauma in $1.7 \%$ (2); prematurity in $2.5 \%$ (3). The remaining 18 cases (15.1\%) had unknown causes and were classified as idiopathic SNHL.

\section{PCR results}

Viral DNA was extracted from the perilymphatic fluid of $5 / 18$ idiopathic 
SNHL cases. CMV or HSV DNAs were detected in $3 / 18$ cases (16.7\%) by conventional PCR. Weakly positive CMV DNA was detected in 2 of these cases and the presence of CMV DNA was confirmed by realtime PCR. Both children were aged $<2$ years old. One case was premature and had asphyxia and 1 case had icter without a definite diagnosis. HSV DNA was found in the perilymphatic fluid of 1 of the cases. This was a 3-year-old girl with normal physical examination. The causes of the 2 other cases were not established. Other viral infections (influenza, rubella, adenovirus, mumps, etc.) might be the etiologic factor for these 2 cases with unknown infections for which DNA was extracted. The primers for those infections were not available for testing.

\section{Serological results}

Previous immunity (IgG) against CMV and HSV-1 was detected in all of the 11 idiopathic SNHL cases tested serologically. Toxoplasma IgM was detected in 7 cases $(63.6 \%)$ and 1 case had concomitant positive Toxoplasma IgG test. Previous rubella infection (rubella $\operatorname{IgG}$ ) was detected only in 1 case; this was a 7 -month-old girl without other abnormalities.

\section{Discussion}

Familial and genetic causes have been implicated in the etiology of deafness in previous studies in the Islamic Republic of Iran $[15,16]$. Nevertheless, our study has demonstrated that, as in other developing countries, preventable causes for SNHL persist in our country. In addition to the postnatally known infectious causes diagnosed (mumps, chickenpox, sepsis, otitis media, etc.), possible viral causes were identified in a number of the cases of idiopathic SNHL. CMV or HSV active infections were detected by DNA-PCR in the perilymphatic fluid of 3/18 cases of idiopathic SNHL (confirmed by serology) and specific antibodies against CMV, Toxoplasma spp., HSV-1 or rubella were detected in the serum of $11 / 11$ cases of idiopathic SNHL analysed. The present study therefore provides further evidence of a role for viral infectious causes (known and unknown) in children requiring cochlear implants. The virological and serological results in the present study are very close to previous studies in our centre [12,13], where the rate of both CMV and T. gondii infections in SNHL cases were higher than in normal controls, although this was not true for other infections, such as mumps and rubella.

Sugiura et al. reported the presence of CMV DNA in inner ear samples for the first time [10]. Our study is the second done in children with idiopathic SNHL who needed cochlear implantation surgery. Herpes family viruses (CMV and HSV) were isolated from the perilymphatic fluid (end organ) of $3 / 18$ of our cases of idiopathic SNHL. The serological examination confirmed the results. We observed acute Toxoplasma spp. infection in 7/11 cases of idiopathic SNHL tested. All of these cases had previous immunity (IgG) against CMV and HSV-1. Previous rubella infection ( $\mathrm{IgG}$ ) was found in only 1 case, probably due to the rubella vaccination programme in the Islamic Republic of Iran during the last decade. The data from the present study are also similar to those of Davis et al., in which CMV infection in the inner ear fluid was identified as the most common cause of nonhereditary SNHL in children [9].

Other evidence of a viral aetiology for SNHL has been reported. Foulon et al. reported a 10-year prospective study of 74 children with congenital CMV infection in which $22 \%$ of cases developed SNHL [4]. Lackner et al. documented the effect of ganciclovir therapy on hearing preservation for asymptomatic congenital CMV infection with 10-year follow up [17]. Mishra et al. in
Nepal, however, found no evidence that sudden deafness was associated with a systemic viral infection, although they studied cases by serology without any search for the DNA of the infectious agents [18].

CMV can persist within the inner ear for prolonged periods following congenital infection. Approximately, $14 \%$ of children with congenital CMV infection develop SNHL of some type, and 3\%-5\% develop bilateral moderate to profound SNHL [3-7]. It has been hypothesized that bloodborne viruses passes from the stria vascularis into the endolymphatic spaces and infect the epithelium [8-10]. Neonatal screening for intrauterine infection and neonatal hearing loss have been recommended by many authors [15,17,19-22]. However, the diagnosis of intrauterine and perinatal CMV infection only by serological examination is difficult [3-8]. Detection of antibodies or virus in urine after the first year of life is of no use as most children develop immunity to the virus. Nucleic acid testing has allowed more sensitive and specific detection of infectious agents particularly for viruses $[9,10]$. A test based on viral DNA extraction from neonatal dried blood spots on Guthrie cards is a useful method. Different CMV DNAPCR protocols have been evaluated for analysis of dried blood spots from consecutive cases of neonates with congenital CMV infections [19-22].

\section{Conclusions}

A possible role for infectious agents (pre- or postnatal) was found in nonhereditary cases of profound SNHL needing cochlear surgery. In addition to known postnatal infections, CMV or HSV active infections (detected by DNA-PCR, confirmed by serology) were found in $16.6 \%$ of SNHL cases and acute T. gondii infection (detected serologically) in $63.6 \%$ of idiopathic SNHL 
cases. These 3 common indolent infections may be acquired in the intrauterine or postnatal period. We were not able to differentiate congenital from acquired (peri-or postnatal) sources of these infections. Routine intrauterine infection screening tests (such as the
TORCH screen) are unavailable in the Islamic Republic of Iran [11]. The costs of neonatal screening, diagnosis and follow-up should be estimated and weighed up against the financial and emotional burden of hearing loss on the children and their families.

\section{Acknowledgements}

This study was supported by the Research Centres for Ear, Nose and Throat Diseases, Head and Neck Surgery and Paediatric Infectious Diseases affiliated to the Tehran University of Medical Sciences.

\section{References}

1. Sensorineural hearing loss. Wikipedia [website] (http:// en.wikipedia.org/wiki/Hearing_loss,_sensorineural, accessed 4 September 2011).

2. Kountakis SE. Risk factors for hearing loss in neonates: a prospective study. American Journal of Otolaryngology, 2002, 23:133-137.

3. Bradford RD et al. Detection of cytomegalovirus (CMV) DNA by polymerase chain reaction is associated with hearing loss in newborns with symptomatic congenital CMV infection involving the central nervous system. Journal of Infectious Diseases, 2005, 191:227-233.

4. Foulon I et al. A 10-year prospective study of sensorineural hearing loss in children with congenital cytomegalovirus infection. Journal of Pediatrics, 2008, 153:84-88.

5. Grosse SD, Ross DS, Dollard SC. Congenital cytomegalovirus $(\mathrm{CMV})$ infection as a cause of permanent bilateral hearing loss: a quantitative assessment. Journal of Clinical Virology, 2008, 41:57-62.

6. Fowler KB, Boppana SB. Congenital cytomegalovirus (CMV) infection and hearing deficit. Journal of Clinical Virology, 2006, 35:226-31.

7. Rosenthal LS et al. Cytomegalovirus shedding and delayed sensorineural hearing loss: results from longitudinal follow-up of children with congenital infection. Pediatric Infectious Disease Journal, 2009, 28:515-520.

8. Iwasaki $S$ et al. Audiological outcome of infants with congenital cytomegalovirus infection in a prospective study. Audiology and Neuro-Otology, 2007, 12:31-36.

9. Davis LE et al. Recovery and probable persistence of cytomegalovirus in human inner ear fluid without cochlear damage. Annals of Otology, Rhinology, and Laryngology, 1987, 96:380-383.

10. Sugiura $\mathrm{S}$ et al. Detection of human cytomegalovirus DNA in perilymph of patients with sensorineural hearing loss using real-time PCR. Journal of Medical Virology, 2003, 69:72-75.

11. Noorbakhsh $\mathrm{S}$ et al. Study of TORCH suspected infants. Iranian Journal of Pediatrics, 2005, 5(Suppl. 1):87.
12. Noorbakhsh S, Farhadi M, Tabatabaei A. Infection in childhood sensory hearing loss. Saudi Medical Journal, 2008, 29:1470-1474.

13. Samileh $\mathrm{N}$ et al. Role of cytomegalovirus in sensorineural hearing loss of children: a case-control study Tehran, Iran. International Journal of Pediatric Otorhinolaryngology, 2008; 72:203-208.

14. Noorbakhsh S et al. Sensorineural hearing loss due to Toxoplasma gondii in children: a case-control study. Clinical Otolaryngology, 2008, 33:269-273.

15. Najmabadi $\mathrm{H}$ et al. Genetic study of the Iranian deaf population. Journal of Medical Genetics, 2005, 42(2, Suppl. 1):S108.

16. Najmabadi H et al. GJB2 mutations: passage through Iran. American Journal of Medical Genetics. Part A, 2005, 133A(2):132-137.

17. Lackner $A$ et al. Effect on hearing of ganciclovir therapy for asymptomatic congenital cytomegalovirus infection: four to 10 year follow up. Journal of Laryngology and Otology, 2008, 123:1-6.

18. Mishra B et al. Viral infections in sudden hearing loss. Do we have enough evidence? Kathmandu University Medical Journal, 2005, 3:230-233.

19. Mizuno T et al. Detection of cytomegalovirus DNA in preserved umbilical cords from patients with sensorineural hearing loss. European Archives of Oto-Rhino-Laryngology, 2009, 266:351-355.

20. Soetens $\mathrm{O}$ et al. Evaluation of different cytomegalovirus (CMV) DNA PCR protocols for analysis of dried blood spots from consecutive cases of neonates with congenital CMV infections. Journal of Clinical Microbiology, 2008, 46:943-946.

21. Ogawa $\mathrm{H}$ et al. Congenital cytomegalovirus infection diagnosed by polymerase chain reaction with the use of preserved umbilical cord in sensorineural hearing loss children. Laryngoscope, 2006, 116:1991-1994.

22. Walter $\mathrm{S}$ et al. Congenital cytomegalovirus: association between dried blood spot viral load and hearing loss. Archives of Disease in Childhood. Fetal and Neonatal Edition, 2008, 93:F280-285. 